Grzyby drożdżoidalne występujące na ziarniakach pszenicy. IV. Studium taksonomiczne szczepów Cryptococcus laurentii (Kuff.) Skinner var. laurentii i var. flavescens (Saito) Lodder et Kreger-van Rij

\title{
ZOFIA MACIEJOWSKA-POKACKA
}

Instytut Ochrony Roślin, Poznań

\begin{abstract}
Maciejowska-Pokacka Z.: (Institute of Plant Protection, Poznan, Miczurina 20, Poland). Yeasts occurring on wheat seeds. IV. A taxonomic study of strains of Cryptococcus laurentii (Kuff.) Skinner var. laurentii and var. flavescens (Saito) Lodder et Kreger-van Rij. Acta Mycol. 13(1): 3-9, 1977.

Morphology and physiology of strains of Cryptococcus laurentii var. laurentii and var. flavescens was studied. Morphological features found in var. laurentii suggested a close relation to Sporobolomycetaceae, and in particular to Bullera alba (Hanna) Derx.
\end{abstract}

\section{WSTĘP}

W dotychczasowych badaniach mikoflory ziarna zbóż rzadko uwzględniano zróżnicowanie gatunkowe grzybów drożdżoidalnych, a czasem pomijano tę grupę calkowicie. O pospolitym występowaniu grzybów z gatunku Cryptococcus laurentii (Kuff.) Skinner na ziarnie pszenicy doniósł po raz pierwszy Kurtzman i wsp. (1970). Maciejowska-Pok a c k a (1976 b) badając zróżnicowanie gatunkowe i odmianowe grzybów wyosobnionych z ziarniaków pszenicy i należących do tego rodzaju stwierdzila, że jedną z najpospolitszych była odmiana C. laurentii (Kuff.) Skinner var. magnus Lodder et Kreger-van Rij. Dalsze badania wykazały, że na ziarnie pszenicy jeszcze liczniej występowała odmiana C. laurentii (Kuff.) Skinner var. laurentii. Natomiast odmiana C. laurentii (Kuff.) Skinner var. flavescens (Saito) Lodder et Kreger-van Rij, która nie była dotychczas wyosobniona $\mathrm{z}$ ziarniaków zbóż, występowala na badanym przez autorkę materiale sporadycznie.

Lodder i Kreger-van Rij (1952) określając odmiany C. laurentii posługiwały się kryteriami morfologicznymi, a mianowicie var. magnus różniła się ich zdaniem od typowego szczepu $C$. laurentii obec- 
nością kulistych i większych komórek wegetatywnych, podczas gdy var. flavescens wytwarzała komórki o nieregularnym kształcie. Phaff i Fell (1970) podają z kolei, że odmiany C. laurentii można rozpoznać badając zróżnicowanie zdolności asymilacji niektórych skladników pokarmowych. Badane przez nich szczepy var. laurentii wykazywaly bowiem zdolność pobierania erytrytu i melibiozy, szczepy var. magnus nie pobieraly tych skladników, a szczepy var. flavescens asymilowaly melibiozę, lecz nie zużywaly erytrytu.

Do gatunku C. laurentii są zaliczane szczepy o określonych wlaściwościach fizjologicznych i o białawej, kremowej, żółtawej lub różowawej barwie kolonii. Ich mikroskopowe cechy morfologiczne są malo specyficzne. Faza wegetatywna składa się tu głównie, podobnie jak $u$ wielu innych gatunków i rodzajów grzybów drożdżoidalnych, z owalnych lub kulistych komórek pącżkujących, a wytwarzanie prymitywnej nibygrzybni i grzybni, którą ostatnio stwierdzil K urtzman (1973), jest zjawiskiem rzadkim. Poza tym kultury szczepów tej samej odmiany mogą być gładkie lub szorstkie, pastowate lub śluzowate.

Szczepy var. laurentii występują pospolicie na różnych nadziemnych częściach roślin, a ponadto w wodach słodkich i slonych, winie, piwie, gumach roślinnych, ciele bezkręgowców, m.in. organizmach planktonowych, owadach oraz w powietrzu. W sporadycznych przypadkach wyosobniono je także z innych źródel, na przyklad z tchawicy ludzkiej. Natomiast obecność C. laurentii var. flavescens stwierdzono w powietrzu; według dotychczasowych opinii odmiana ta należy do organizmów rzadkich (Phaff, Fell 1970).

\section{MATERIAL I METODY}

Dane dotyczące materialu i stosowanych metod badawczych podano w poprzedniej publikacji (M a ciejow ska-Pok a ck a 1976 a). Badania taksonomiczne, których wyniki przedstawiono w niniejszej pracy, przeprowadzono na 50 szczepach $C$. laurentii var. laurentii i 8 szczepach var. flavescens, wyosobnionych z ziarniaków pszenicy w latach 1971-1974.

\section{WYNIKI I DYSKUSJA}

Liczebność występowania oraz cechy fizjologiczne obu badanych odmian podano $\mathrm{w}$ tabelach 1 i 2 . Jak widać (tab. 1) szczepy C. laurentii var. laurentii występowały glównie na ziarniakach nie odkażonych, podobnie jak szczepy $C$. laurentii var. magnus (M a ci e jow ska-Pokacka 1976 b). Na ziarniakach zebranych 5, 6 i 7 dni przed żniwami liczba szczepów tej odmiany byla nieco wyższa, niż na ziarniakach o pełnej 
Tabela $1-$ Table 1

Cryptococcus laurentii var. laurentii i var. flavescens

Liczeoność szczepów w mikoflorze wyosobnionej z ziarniaków pszenicy Number of strains in mycoflora isolated from wheat seeds

\begin{tabular}{|c|c|c|c|c|}
\hline \multirow{2}{*}{$\begin{array}{l}\text { Material używany } \\
\text { do izolacji } \\
\text { Material used } \\
\text { for isolation }\end{array}$} & \multicolumn{4}{|c|}{$\begin{array}{l}\text { Srednia liczba kolonii wyosobnionych z } 1 \mathrm{~g} \text { ziarna } \\
\qquad(0-4 \text { miesiące po zbiorze }) \\
\text { Mean number of colonies isolated from } 1 \mathrm{~g} \text { of seeds } \\
(0-4 \text { months after harvest })\end{array}$} \\
\hline & $\begin{array}{c}\text { grzyby ogólem } \\
\text { fungi total }\end{array}$ & $\begin{array}{c}\text { grzyby } \\
\text { drożdżoidalne } \\
\text { yeasts }\end{array}$ & $\begin{array}{c}\text { var. } \\
\text { laurentii }\end{array}$ & $\begin{array}{c}\text { var. } \\
\text { flavescens }\end{array}$ \\
\hline $\begin{array}{l}\text { Ziarniaki nie odkażane } \\
\text { Non-sterilized seeds }\end{array}$ & 36400 & 2900 & 720 & $<1$ \\
\hline $\begin{array}{l}\text { Ziarniaki odkażane } \\
\text { Sterilized seeds }\end{array}$ & 2830 & 302 & 8 & 0 \\
\hline
\end{tabular}

dojrzałości. Podobną zależność stwierdzono pomiędzy stopniem dojrzałości ziarna i występowaniem gatunków z rodzaju Sporobolomyces Kluyver et van Niel (Maciejow ska-Pokacka 1976 c). Wszystkie szczepy tej odmiany wytwarzaly kolonie o zabarwieniu kremowym lub bladoróżowym, $\mathrm{z}$ wiekiem szarzejącym. Kolonie tych szczepów byly gladkie lub nieco szorstkie, pastowate lub śluzowate, ale nie wodniste jak np. kolonie szczepów C. laurentii var. magnus. Z nieodkażonych ziarniaków wyosobniono ponadto 8 szczepów C. laurentii var. flavescens. Kolonie tych izolatów były kremowe lub żóltawe, gładkie i pastowate.

Szczepy C. laurentii var. laurentii różnily się między sobą nie,tylko cechami makroskopowymi kultur, ale również pod względem mikroskopowym ilościową proporcją komórek małych i dużych. Porównując natomiast strukturẹ mikroskopową kultur var. laurentii $\mathrm{i}$ var. magnus (Maciejowska-Pokacka 1976 b) stwierdzono pomiędzy nimi wyrażne różnice morfologiczne. U szczepów var. laurentii występowaly kuliste komórki o wymiarach 4,1-12,2 $\times 4,1-9,8 \mu \mathrm{m}$, wytwarzające wydlużone pączki (ryc. 12). Na jednym biegunie komórki mogło powstawać sukcesywnie kilka pączków; niekiedy pączki powstawały również $\mathrm{w}$ innych miejscach. W wielu przypadkach pączek powstawał na trzonku podobnym do strzępki kielkowej lub do sterygmy (ryc. 6, 7, 14). Czasem trzonek ten pęcznial i przekształcał się w owalną komórkę (ryc. 8, 13). Pomimo pewnego podobieństwa opisanego tutaj pączkowania przypominającego stadium doskonale Aessosporon van der Walt (1970) wydaje się, że w tym przypadku byla to forma rozwoju wegetatywnego. W kulturach szczepów var. laurentii nie spotykano poza tym tak dobrze wy- 
Tabela $2-$ Table 2

Cryptococcus laurentii var. laurentii $\mathrm{i}$ var. flavescens

Charakterystyka fizjologiczna szczepów wyosobnionych z ziarniaków pszenicy Physiological characteristics of strains isolated from wheat seeds

\begin{tabular}{|c|c|c|c|c|c|}
\hline \multirow[b]{2}{*}{$\begin{array}{l}\text { Wlaściwości } \\
\text { fizjologiczne } \\
\text { Physiological } \\
\text { characteristics }\end{array}$} & \multicolumn{2}{|c|}{ C. laurentii } & \multirow[b]{2}{*}{$\begin{array}{l}\text { Wlaściwości } \\
\text { fizjologiczne } \\
\text { Physiological } \\
\text { characteristics }\end{array}$} & \multicolumn{2}{|c|}{ C. laurentii } \\
\hline & $\begin{array}{l}\text { var. } \\
\text { laure- } \\
\text { ntii }\end{array}$ & $\begin{array}{l}\text { var. } \\
\text { flave- } \\
\text { scens }\end{array}$ & & $\begin{array}{l}\text { var. } \\
\text { laure- } \\
\text { ntii }\end{array}$ & $\begin{array}{l}\text { var. } \\
\text { flave- } \\
\text { scens. }\end{array}$ \\
\hline $\begin{array}{l}\text { Asymilacja } \\
\text { Assimilation }\end{array}$ & & & $\begin{array}{l}\text { Asymilacja } \\
\text { Assimilation }\end{array}$ & & \\
\hline $\begin{array}{l}\text { Glukoza } \\
\text { Glucose }\end{array}$ & + & + & $\begin{array}{l}\text { Glicerol } \\
\text { Glycerol }\end{array}$ & - & $+;-$ \\
\hline $\begin{array}{l}\text { Galaktoza } \\
\text { Galactose }\end{array}$ & + & + & $\begin{array}{l}\text { Erytryt } \\
\text { Erythritol }\end{array}$ & + & - \\
\hline $\begin{array}{l}\text { L-sorboza } \\
\text { L-sorbose }\end{array}$ & + & + & $\begin{array}{l}\text { Ribitol } \\
\text { Ribitol }\end{array}$ & $+;-$ & $\pm ;-$ \\
\hline $\begin{array}{l}\text { Sacharoza } \\
\text { Saccharose }\end{array}$ & + & + & $\begin{array}{l}\text { Dulcyt } \\
\text { Galactitol }\end{array}$ & + & + \\
\hline $\begin{array}{l}\text { Maltoza } \\
\text { Maltose }\end{array}$ & + & + & $\begin{array}{l}\text { Mannit } \\
\text { Marnitol }\end{array}$ & + & + \\
\hline $\begin{array}{l}\text { Celobioza } \\
\text { Cellobiose }\end{array}$ & + & + & $\begin{array}{l}\text { Glucitol } \\
\text { Glucitol }\end{array}$ & + & + \\
\hline $\begin{array}{l}\text { Trehaloza } \\
\text { Trehalose }\end{array}$ & + & + & $\begin{array}{l}a \text {-metyl-D-glukozyd } \\
a \text {-methyl-D-glucoside }\end{array}$ & + & + \\
\hline $\begin{array}{l}\text { Laktoza } \\
\text { Lactose }\end{array}$ & + & + & $\begin{array}{l}\text { Salicyna } \\
\text { Salicin }\end{array}$ & + & + \\
\hline $\begin{array}{l}\text { Melibioza } \\
\text { Melibiose }\end{array}$ & + & + & $\begin{array}{l}\text { DL-kwas mlekowy } \\
\text { DL-lactic acid }\end{array}$ & - & - \\
\hline $\begin{array}{l}\text { Rafinoza } \\
\text { Raffinose }\end{array}$ & + & + & $\begin{array}{l}\text { Kwas bursztynowy } \\
\text { Succinic acid }\end{array}$ & \pm & + \\
\hline $\begin{array}{l}\text { Melezytoza } \\
\text { Melesitose }\end{array}$ & + & + & $\begin{array}{l}\text { Kwas cytrynowy } \\
\text { Citric acid }\end{array}$ & \pm & \pm \\
\hline $\begin{array}{l}\text { Inulina } \\
\text { Inulin }\end{array}$ & - & \pm & $\begin{array}{l}\text { Inożytol } \\
\text { Inositol }\end{array}$ & + & + \\
\hline $\begin{array}{l}\text { Skrobia rozpuszczalna } \\
\text { Soluble starch }\end{array}$ & \pm & \pm & $\begin{array}{l}\text { Wzrost na pożywce bez } \\
\text { witamin }\end{array}$ & - & - \\
\hline $\begin{array}{l}\text { D-ksyloza } \\
\text { D-xylose }\end{array}$ & + & + & $\begin{array}{l}\text { Growth in vitamin-free } \\
\text { medium }\end{array}$ & - & - \\
\hline $\begin{array}{l}\text { L-arabinoza } \\
\text { L-arabinose }\end{array}$ & + & + & $\begin{array}{l}\text { Azotan potasu } \\
\text { Potassium nitrate }\end{array}$ & - & - \\
\hline $\begin{array}{l}\text { D-arabinoza } \\
\text { D-arabinose }\end{array}$ & + & \pm & $\begin{array}{l}\text { Azotyn potasu } \\
\text { Potassium nitrite }\end{array}$ & - & - \\
\hline $\begin{array}{l}\text { D-riboza } \\
\text { D-ribose }\end{array}$ & + & + & $\begin{array}{l}\text { Wytwarzanie związków } \\
\text { skrobiopodobnych }\end{array}$ & + & + \\
\hline $\begin{array}{l}\text { L-ramnoza } \\
\text { L-rhamnose }\end{array}$ & + & + & $\begin{array}{l}\text { Formation of starch-like } \\
\text { compounds }\end{array}$ & + & + \\
\hline $\begin{array}{l}\text { Etanol } \\
\text { Ethanol }\end{array}$ & \pm & \pm & $\begin{array}{l}\text { Rozpuszczanie żelatyny } \\
\text { Gelatin liquefaction }\end{array}$ & - & - \\
\hline
\end{tabular}


kształconych, jak u szczepów var. magnus, trójkomórkowych i trójdzielnych elementów (M a ci e jow s k a - P o k a c k a 1976 b). Występował tu natomiast inny, charakterystyczny element morfologiczny, mianowicie komórki o kształcie zbliżonym do wrzecionowatego (ryc. 4) i o wymiarach 5,1-14,7 $\times 2,0-4,5 \mu \mathrm{m}$, które mogły pączkować na obydwóch lub na jednym biegunie. Podobne komórki spotykano u grzybów z rodzaju Sporobolomyces (Maciejow ska-Pokacka 1976 c). Większość komórek wykazywala jednak prosty, jednobiegunowy typ pączkowania.

W kulturach szczepów C. laurentii var. laurentii wyróżniono 2 generacje komórek: małe, wydlużone komórki o wymiarach 1,9-7,3 $\times 1,1$ $3,2 \mu \mathrm{m}$, przypuszczalnie w stadium haplofazy (ryc. $1,2,3,10$ ) oraz większe komórki o kształcie owalnym lub zbliżonym do kulistego, o wymiarach $3,3-14,8 \times 3,1-12,9 \mu \mathrm{m}$, przypuszczalnie w stadium diplofazy (ryc. 2, 3). Duże komórki powstawały z komórek małych, podobnie jak u szczepów Sporobolomyces (M a ciejow s k a-Pokacka 1976 c). Proces ten byl prawdopodobnie wynikiem somatycznej autogamii, ponieważ nie obserwowano konjugacji dwóch niezależnych komórek. Ponadto w kulturach szczepów C. laurentii var. laurentii występowały elementy prymitywnej nibygrzybni i chlamydospory (ryc. 11).

Powstawanie zarodników na trzonkach przypominających sterygmy wskazuje na pokrewieństwo szczepów C. laurentii var. laurentii z grzybami z rodziny Sporobolomycetaceae, a zwlaszcza z rodzajem Bullera Derx. Wskazują na to również identyczne właściwości fizjologiczne trzech odmian C. laurentii i gatunku Bullera alba (Hanna) Derx (P h a f f 1970; $\mathrm{Ph}$ aff, Fell 1970). Ponieważ zdolność wytwarzania balistospor u szczepów Bullera może zanikać, brak jest w takim przypadku kryteriów, na podstawie których można by odróżnić je od szczepów C. laurentii ( $\mathrm{P}$ h a f f 1970). Ponadto oryginalne szczepy Bullera alba zostały wyosobnione ze słomy pszennej i owsianej porażonej rdzą. Obydwa gatunki występują więc w tym samym środowisku naturalnym, co stanowi dodatkowy argument pozwalający na przypuszczenie, że szczepy $C$. laurentii var. laurentii opisane w niniejszej pracy są w rzeczywistości szczepami Bullera alba pozbawionymi zdolności wytwarzania balistospor.

Kultury badanych szczepów C. laurentii var. flavescens składały się przeważnie z mniej lub bardziej wydłużonych komórek owalnych. Charakterystycznym elementem tych kultur byly jednak komórki o nieregularnych kształtach i komórki kolankowate (ryc. 18-21, 23-26). Wszystkie te formy reprezentowały różny stopień i różny kierunek rozwoju potrójnych elementów, typowych dla C. laurentii var. magnus i C. albidus var. albidus (Maciejow ska-Pokacka 1976 b). W kulturach C. laurentii var. flavescens niekiedy znajdowano również komórki wytwarzające pączki na trzonku podobnym do sterygmy (ryc. 22). Zwykle jednak za- 
miast trzonka powstawała bazypetalnie druga komórka (ryc. 32). Te dwie komórki najczęściej nie rozdzielały się, lecz lączyły, a formą pośrednią była komórka bliźniacza (ryc. 29, 32). W starszych kulturach C. laurentii var. flavescens występowały charakterystyczne komórki owalne lub gruszkowate o gęstej cytoplazmie (ryc. 28, 30). Niezależnie od wieku w kulturach tej odmiany powstawały komórki olbrzymie (ryc. 17). Zasadniczym sposobem pączkowania było pączkowanie proste, jednobiegunowe (ryc. 16, 33), podobnie jak u szczepów var. laurentii. Szczepy var. flavescens wytwarzały także elementy prymitywnej nibygrzybni (ryc. $23,27,31$ ). W kulturach wyróżniono 2 generacje komórek: małe, owalne komórki o wymiarach $2,8-7,3 \times 1,6-3,5 \mu \mathrm{m}$ przypuszczalnie w stadium haplofazy (ryc. 16) i wydłużone lub owalne, większe komórki o wymiarach 4,4-15,0 X1,7$12,0 \mu \mathrm{m}$ przypuszczalnie w stadium diplofazy (ryc. 16, 19).

Na podstawie przeprowadzonych badań można wyciągnąc następujące wnioski: 1) badane szczepy $C$. laurentii var. laurentii różnily się wyraźnie pod względem cech morfologicznych od szczepów C. laurentii var. magnus i var. flavescens; 2) szczepy C. laurentii var. laurentii miały cechy morfologiczne i fizjologiczne wskazujące na bliskie pokrewieństwo z grzybami z rodziny Sporobolomycetaceae, a zwlaszcza z Bullera alba; 3) badane szczepy $C$. laurentii var. flavescens wytwarzały charakterystyczne komórki o nieregularnych ksztaltach oraz komórki kolankowate. Na podstawie ostatniej cechy można było je latwo odróżnić od szczepów dwóch pozostałych odmian C. laurentii.

Autorka dziękuje dr N. J. W. Kreger-van Rij z Laboratorium voor Medische Microbiologie Rijks Universiteit, Groningen, Holandia za sprawdzenie poprawności oznaczenia szczepu nr 55 C. laurentii var. laurentii.

\section{Tablica I - Plate I \\ Cryptococcus laurentii (Kuff.) Skinner var. laurentii}

szczep nr 55: 1, 4, 5 - fragmenty kultur na agarze kukurydzianym po 4 dniach; 2, 3 - fragmenty kultur na agarze ziemniaczanym z glukozą po 4 i 5 dniach; 5-8 powstawanie pączków na niektórych komórkach w stadium domniemanej diplofazy; szczep nr 126: 9 - fragment kultury na agarze ziemniaczanym z glukozą po 3 dniach; 10, 15 - fragmenty kultur na agarze kukurydzianym po 3 dniach; 11 - chlamydospory; 12-14 - powstawanie pączków na niektórych komórkach w stadium domniemanej diplofazy

strain No. 55: 1, 4, 5 - fragments of cultures on cornmeal agar after 4 days; 2, 3 fragments of cultures on PDA after 4 and 5 days; 5-8 - formation of buds on some cells of presumed diplophase;

strain No. 126: 9 - fragment of a culture on PDA after 3 days; 10, 15 - fragments of cultures on cornmeal agar after 3 days; 11 - chlamydospores; $12-14$ - formation of buds on some cells of presumed diplophase 
Tablica I - Plate I

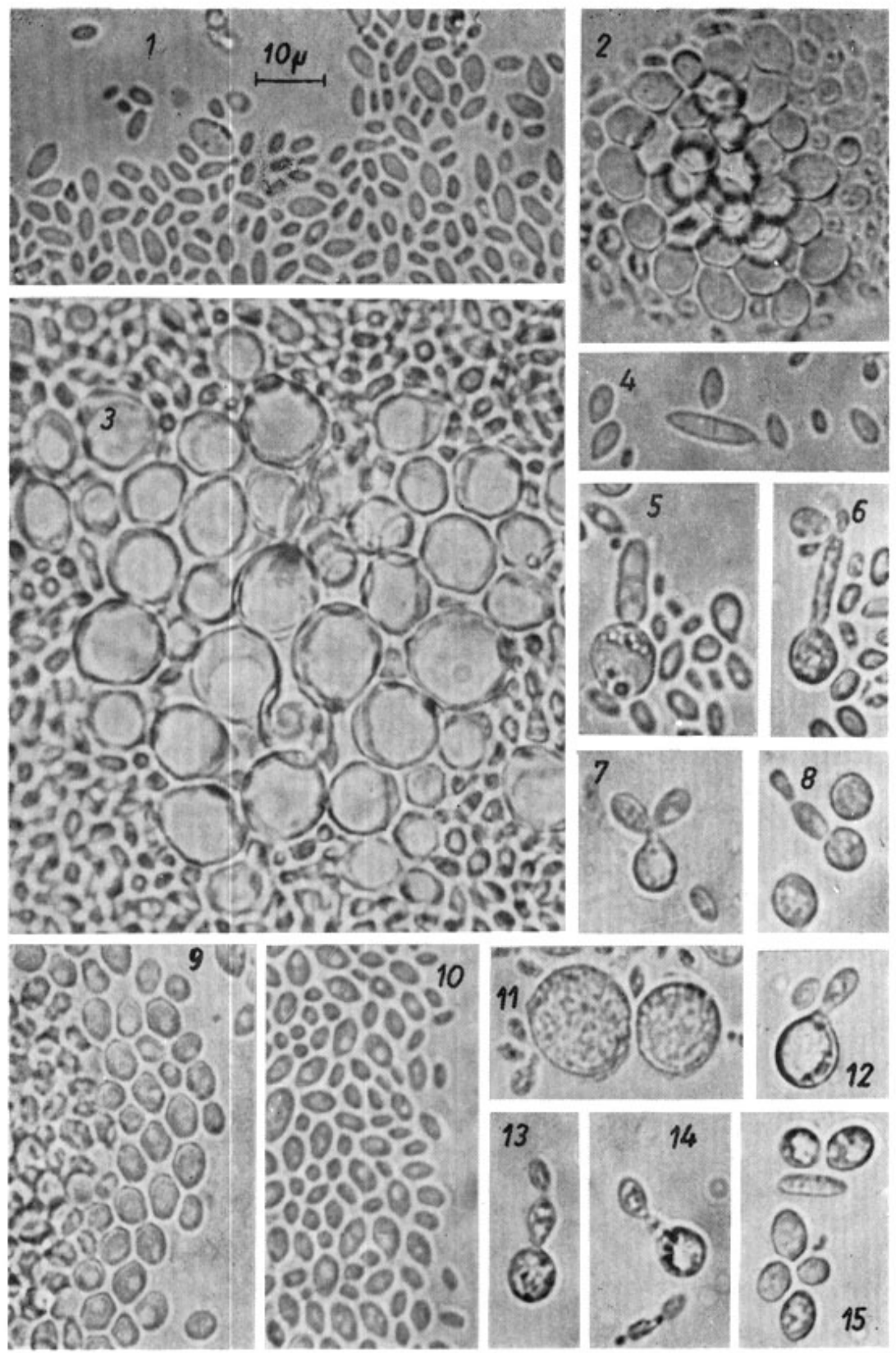




\section{Tablica II - Plate II}

Cryptococcus laurentii (Kuff.) Skinner var. flavescens (Saito) Lodder et Kreger-van $\mathrm{Rij}$

szczep $\mathrm{nr}$ 121: 16, 18-21, 23-26 - fragmenty kultur na agarze kukurydzianym, z komórkami o nieregularnym ksztalcie reprezentującymi różne stadia rozwoju elementów trójdzielnych; 17 - komórka olbrzymia w kulturze na agarze ziemniaczanym z glukozą; 22 - powstawanie pączka na trzonku podobnym do sterygmy; strain No. 121: 16, 18-21, 23-26 - fragments of cultures on cornemeal agar with cells of irregular shape representing various stages of development of triple elements: 17 - a giant cell in a culture on PDA; 22 - formation of a bud on a sterigma-like stalk 


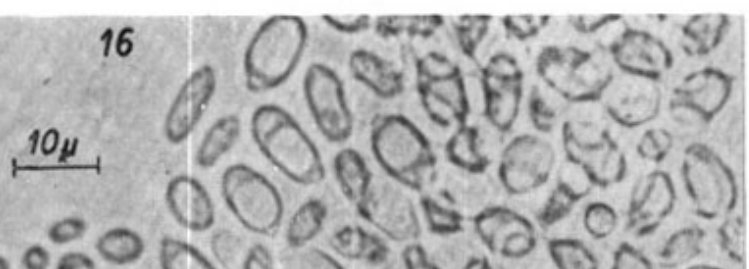

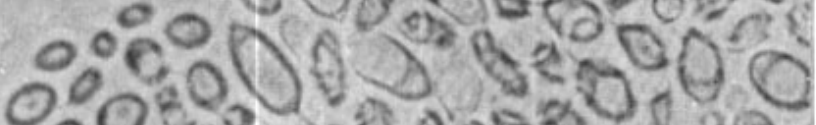

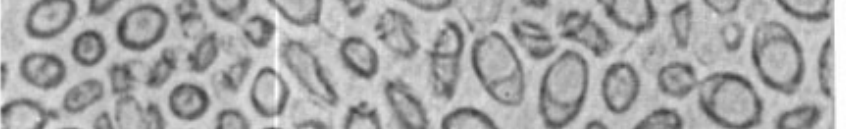

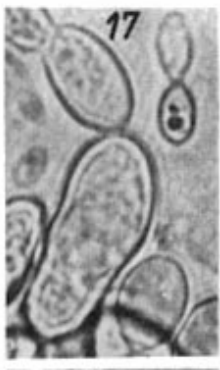

201000000000 $380.0 \% 0.9000$

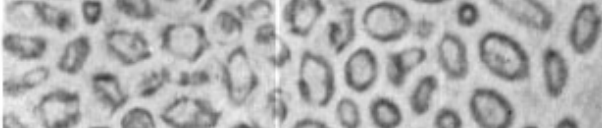

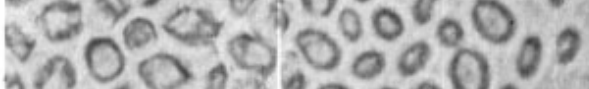
s.
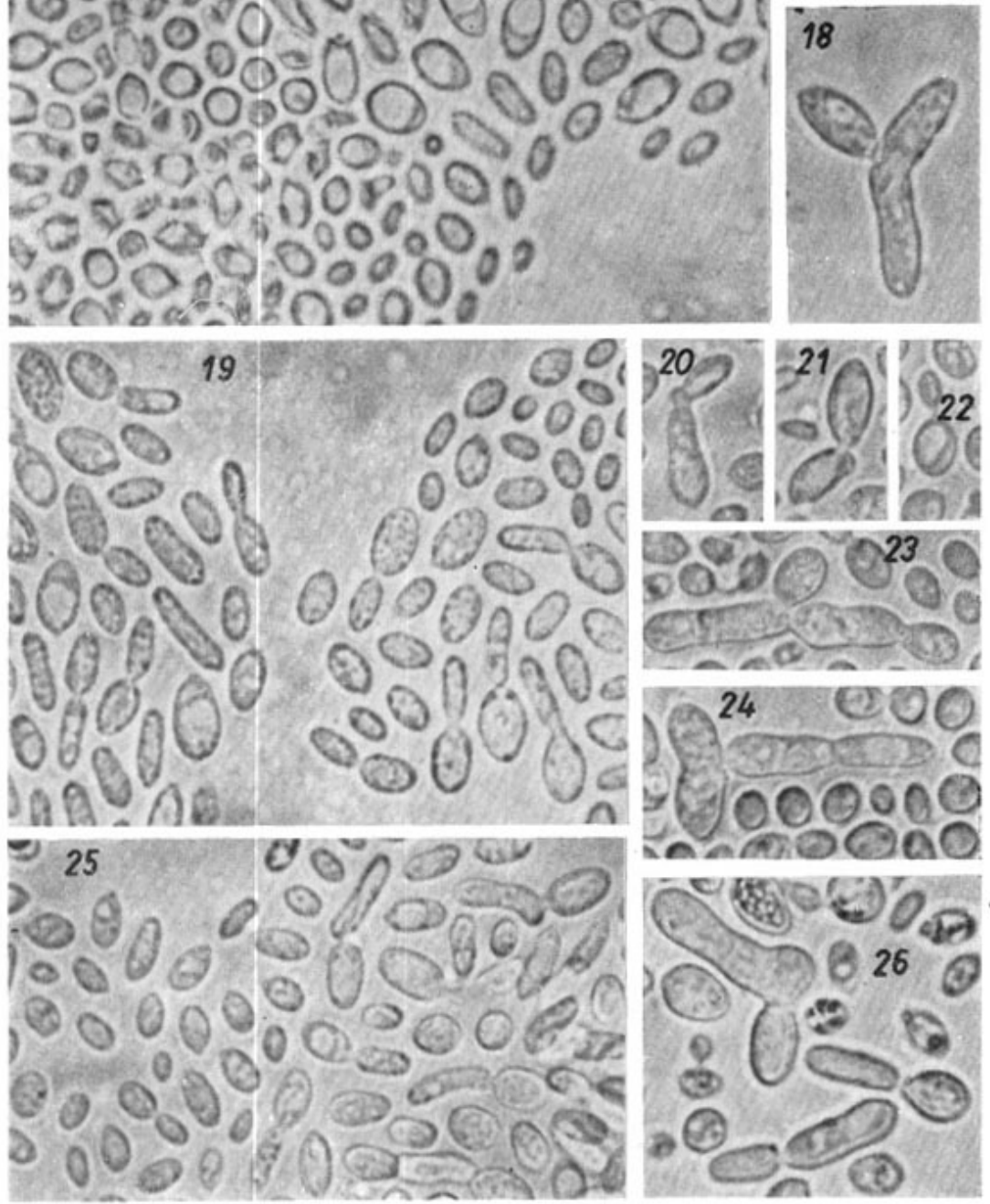
Tablica III - Plate III
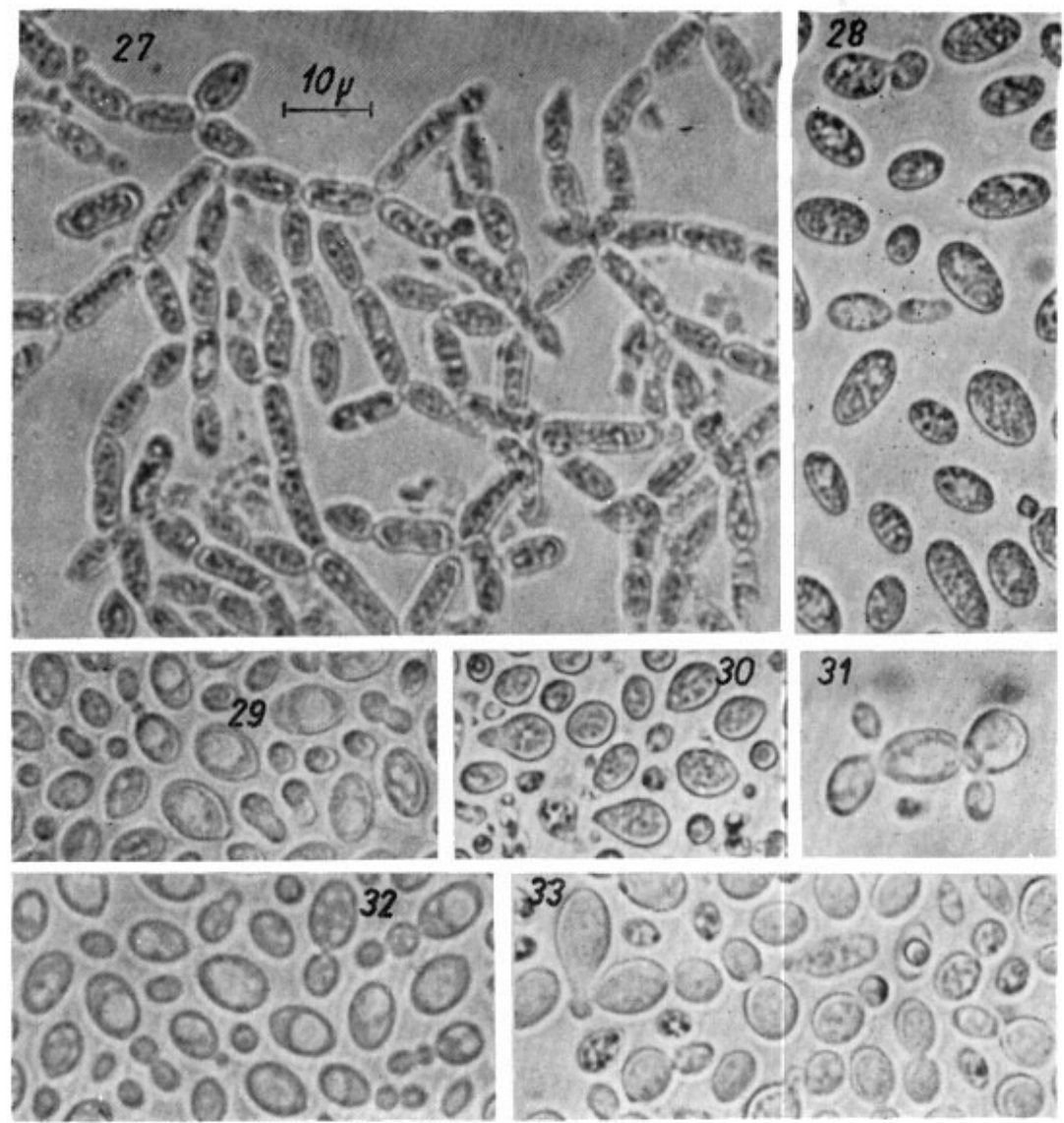

Cryptococcus laurentii (Kuff.) Skinner var. flavescens (Saito) Lodder et Kreger-van Rij

szczep nr 121: 27 - fragment kultury w mineralnej pożywce plynnej z maltozą po 3 tygodniach: 28, 30 - owalne i gruszkowate komórki w starej kulturze na agarze ziemniaczanym z glukozą; 29, 31-33 - fragmenty 4-dniowych kultur na agarze kukurydzianym; na ryc. 29 i 32 widać różne stadia rozwoju dwóch kolejnych pączków powstających na większych, owalnych komórkach

strain No. 121: 27 - fragment of a culture in a liquid mineral medium with maltose after 3 weeks; 28, 30 - oval and pear-shaped cells in an old culture on PDA; $29,31-33$ - fragments of 4-day-old cultures on cornmeal agar; on figs. 29 and 32 are seen various stages of development of two successive buds formed on larger oval cells 


\section{SUMMARY}

The paper is concerned with the morphology and physiology of strains of Cryptococcus laurentii (Kuff.) Skinner var. laurentii and var. flavescens (Saito) Lodder et Kreger-van Rij isolated in the years 1971-1974 from 5 varieties of winter wheat seeds and from 4 regions of Poland. Morphological characters found in strains of C. laurentii var. laurentii indicated that they were related to Sporobolomycetaceae, and especially to Bullera alba (Hanna) Derx. In strains Cryptococcus laurentii var. flavescens irregular, polymorph and knee-shaped cells were found this feature was highly characteristic for the variety flavescens.

\section{LITERATURA}

Kurtzman C. P., 1973, Formation of hyphae and chlamydospores by Cryptococcus laurentii, Mycologia. 65: 388-395.

Kurtzman C. P., Wickerham L. J., Hessletine C. W., 1970, Yeasts from wheat and flour, Mycologia. 62: 542-547.

Lodder J., Kreger-van Rij N. J. W., 1952, The yeasts. Amsterdam-London.

Maciejowska-Pokacka Z., 1976a, Grzyby drożdżoidalne występujące na ziarniakach pszenicy. I. Studium taksonomiczne szczepów Candida albicans (Robin) Berkhout i C. tropicalis (Cast.) Berkhout, Acta Mycol. 12 (1): 113-122.

Maciejowska-Pokacka Z., 1976 b, Grzyby drożdżoidalne występujące na ziarniakach pszenicy. II. Studium taksonomiczne szczepów Cryptococcus laurentii (Kuff.) Skinner var. magnus Lodder et Kreger-van $\mathrm{Rij}$ i C. albidus (Saito) Skinner var. albidus, Acta Mycol. 12 (2) : 195-202.

Maciejowska-Pokacka Z., 1976 c, Grzyby droźdżoidalne występujące na ziarniakach pszenicy. III. Studium taksonomiczne szczepów Sporobolomyces roseus Kluyver et van Niel. i S. pararoseus Olson et Hammer. Acta Mycol. 12 (2): 203-210.

Ph aff H. J., 1970, Bullera Derx, [in:] Lodder J., ed., The yeasts, Amsterdam-London.

Phaff H. J., Fell J. W., 1970, Cryptococcus Kützing emend. Phaff et Spencer, [in:] Lodder J., ed., The yeasts, Amsterdam-London.

W a 1 t P. J., van der, 1970, The perfect and imperfect states of Sporobolomyces salmonicolor, Antonie van Leeuwenhoek, 36: 49-55. 